\title{
Sample Biochemical Methane Potential from the Digestion of Domestic Mixed Sewage Sludge in Batch Tests
}

\author{
Roslinda Seswoya , Ahmad Tarmizi Abdul Karim* \\ ${ }^{\#}$ Micropollutant Research Centre, Faculty of Civil and Environmental Engineering, Universiti Tun Hussein Onn Malaysia, \\ Parit Raja, 86000, Malaysia \\ E-mail: roslinda@uthm.edu.my \\ "Micropollutant Research Centre, Faculty of Civil and Environmental Engineering, Universiti Tun Hussein Onn Malaysia, \\ Parit Raja, 86000, Malaysia \\ E-mail:tarmizi@uthm.edu.my
}

\begin{abstract}
Biochemical methane potential (BMP) is a standard test to assess the biogas (including methane) production from the anaerobic digestion of any organic waste. In many anaerobic digestions of sewage sludge, the inoculum to substrate ratio and mixing were variable to take into consideration for efficient performance. However, the organic content in sewage sludge varied due to the composition of the raw wastewater being treated and the treatment condition. This study is focused on the methane production from the digestion of domestic mixed sewage sludge in the batch reactor at different organic contents. Biochemical methane potential (BMP) was conducted at the inoculum to substrate ratio (I/S) ratio of 2:0, each with different organic content. On the termination day of the BMP assay, the sample from each BMP reactor was tested for $\mathrm{pH}$, and alkalinity to determine the status of the anaerobic process. Results showed that the anaerobic process was stable since the $\mathrm{pH}$ remained in the $\mathrm{pH}$ range which is suitable for the anaerobic process to take place. The anaerobic process was also confirmed stabled as indicated by low value $(<0.3)$ of intermediate alkalinity to partial alkalinity ratio (IA/PA). The ultimate methane yield was $588.3 \mathrm{ml} \mathrm{CH}_{4} / \mathrm{g}$ VS at the organic content of 0.52 and $1244.5 \mathrm{ml} \mathrm{CH}_{4} / \mathrm{g} \mathrm{VS}$ at the organic content of 0.68 respectively. For the organic content of 0.68 , the maximum methane production rate constant was $13.97 \mathrm{~mL} \mathrm{CH} / \mathrm{g}$ VS /hr. For the case of lower organic content, the maximum methane production rate constant was $6.41 \mathrm{~mL} \mathrm{CH}_{4} / \mathrm{g} \mathrm{VS} / \mathrm{hr}$. However, the lag phase of the methane yield curve for both organic content was less than one (1) day, showing the good biodegradability of domestic mixed sewage sludge.
\end{abstract}

Keywords - domestic; organic content; methane yield; production rate

\section{INTRODUCTION}

Anaerobic digestion is a biochemical process produced biogas (including methane) as a final product. The anaerobic digestion process is achieved through several stages: hydrolysis, acidogenesis and methanogenesis. Methanogenesis is the last stage where the mixed methanogenic bacteria consume acetic acid, hydrogen, and some carbon dioxide to produce methane, as the sole reduced organic compound. The anaerobic process can take place in one reactor or in a two-step reactor. As for two-step reactors, one reactor is for hydrolysis and acidification followed by the second reactor for biogas production [1]. Anaerobic digestion is feasible to be installed in large scale and small scale [2].

Anaerobic digestion is applied worldwide for the treatment of different biomass and waste including wheat straw, oil palm, maize, and sewage. Anaerobic digestion is used widely for sewage treatment [3] at mesophilic and thermophilic temperature regime [4]. These two categories refer to broad ranges of operating temperature; $20^{\circ} \mathrm{C}$ to $40^{\circ} \mathrm{C}$ for mesophilic while thermophilic is between $45^{\circ} \mathrm{C}$ to $65^{\circ} \mathrm{C}$. A change of $10^{\circ} \mathrm{C}$ would interfere the reaction rate either halved or doubled. It may also inhibit the process completely. In practice, the temperature control was done as precise as plus or minus one whole degree [5].

Sewage sludge comprises lumpy, flaky and colloidal solids interspersed with water [6]. The large portion of easily biodegradable organic in sewage sludge yields methane-rich biogas $(55-70 \%)$ [7]. In practice, anaerobic digestion is applied to a mixture of primary and secondary (activated waste) sludge [8]. Secondary sludge, a by-product from the conversion of organic matter in activated sludge process is normally known as waste activated sludge (WAS). WAS usually contained organic matter including proteins and carbohydrates [9]. However, primary sewage sludge contained more readily degradable organic matter [10], which is suspended particle [11]. Sewage sludge was 
available in the form of municipal and domestic sludge. Municipal and domestic sewage sludge were different in the way that municipal sewage sludge originated from a municipal treatment plant treating domestic and industrial wastewater [11]. Meanwhile, domestic sewage sludge is a product of the treatment of domestic wastewater.

The problems associated with sewage sludge are a continuous increase in sludge production. Disposal to landfill is restricted due to health and public concern [12]. Besides that, the modern wastewater management needs more allocation for sludge management and disposal [13]. Generally, up to $50 \%$ of the whole cost of operating municipal wastewater treatment plant is allocated for disposal of sewage [14].

Anaerobic digestion at mesophilic temperature is an economical and environmentally friendly approach; able to meet the legislative requirements and reduce the volume of sludge prior to final disposal [12]. Most studies on anaerobic digestion of sewage sludge were focused on municipal sewage sludge due to its availability in most parts of the world [13], [15]-[17].

The global energy demand is satisfied using fossil fuels (including coal, natural gas, etc.). However, environmental issues have become a dilemma due to fossil fuel consumption [18]. Methane from anaerobic digestion is a renewable alternative to fossil fuel [19]. Waste such as sewage sludge is used as a substrate for anaerobic digestion because it contains huge organic matter readily available for the digestion [3]. Anaerobic digestion could be considered as the sustainable treatment of sewage sludge. In this approach the recovery of useful, valuable component achieved. Besides that, the possible adverse impacts of sewage sludge on human and environment are minimized [1]. As a result, several European countries are actively producing electricity from sewage sludge [20].

Biochemical methane potential (BMP) tests is a test to assess the efficiency of anaerobic digestibility and to evaluate the biogas production from targeted waste, e.g. municipal sewage sludge, vinegar residue, switchgrass, and meat-processing wastes [20]-[23]. BMP test was considered as the most suitable method for an easy evaluation on anaerobic digestion [24]. Serum bottle or glass bottle was used for BMP tests [7], [20], [25]. When using the serum or glass bottle as the batch anaerobic reactor, the biogas measurements were carried out manually [26], [27]. In a batch test, the substrate (waste) is incubated in closed serum or glass bottles at a specific temperature (mesophilic or thermophilic) with a specific amount of methanogenic inoculum and the biogas production (including methane) was observed until the biogas production is insignificant. Previously, a batch test was done at the small reactor of 118 $\mathrm{mL}$ to the biggest reactor of $5 \mathrm{~L}$ [11], [28].

Recently, Automatic Methane Potential Test System (AMPTS II) was used to minimize human error in conducting batch BMP assays [26], [29]. Generally, AMPTS II measures only methane by eliminating other gases $\left(\mathrm{H}_{2} \mathrm{~S}\right.$ and $\mathrm{CO}_{2}$ ) [30].

Reference [31] conducted BMP test at batch mode for municipal mixed sewage sludge having the organic content of 0.72 and 0.78 as indicated by VS/TS ratio. VS/TS ratio ranged from 0.75 to 0.79 indicated a high amount of organic matter [32]. Feng, [33] also considered sewage sludge is having high organic content whenever the ratio of $\mathrm{VS} / \mathrm{TS} \geq 0.50$. Therefore, VS/TS ratio which is more than 0.5 (VS/TS $\geq 0.5$ ) was able to be used as an indicator to show higher organic content from waste. On the other hand, Yan, [34] indicated the low organic matter by VS/TS ratio less than 0.5 ( $\mathrm{VS} / \mathrm{TS}<0.5$ ).

The organic content of sewage sludge was related to the methane production as observed from the previous study. The higher ultimate methane potential, $\mathrm{M}_{\mathrm{o}}$ $\left(\mathrm{M}_{\mathrm{o}}>350 \mathrm{~mL} \mathrm{CH} / \mathrm{g} \mathrm{VS}\right)$ was observed at higher VS/TS ratio ( VS/TS > 0.7) [31]. However, at lower VS/TS ratio $(\mathrm{VS} / \mathrm{TS}=0.4)$ the ultimate methane potential, $\mathrm{M}_{\mathrm{o}}$ was less than $30 \mathrm{~mL} \mathrm{CH}_{4} / \mathrm{g}$ VS [34]. However, discussion on the efficiency of inoculum (methanogenic biomass) in producing methane was not included in the study conducted by [31] and [34]. Typically, the efficiency of inoculum particularly methanogenic biomass in producing methane was measured by the specific methanogenic activity and determined using several substrates including acetate, an acid mixture of volatile fatty acid and $\mathrm{H}_{2} / \mathrm{CO}_{2}$ [35]. When acetate is used as the substrate, this process was referred as specific acetoclastic methanogenic activity (SAMA) [35].

The composition of sewage sludge is dictated by the conditions of the treatment plant and the composition of the raw sewage being treated [36]. However, less information has been obtained by the anaerobic digestion of domestic sewage sludge inoculated with anaerobic biomass taken from existing full-scale anaerobic digester; particularly with the different organic content. Therefore, this study was outlined to evaluate the anaerobic digestibility of domestic mixed sewage sludge under the mesophilic condition with different organic contents. The capability of methanogenic biomass in producing methane was included.

\section{MATERIAL AND METHOD}

\section{A. Analytical Methods}

Solids in the form of total solid (TS in $\mathrm{g} / \mathrm{L}$ ), and volatile solid (VS in g/L) were measured following the procedures as described in the Standard Method procedure 2540G [37]. Meanwhile, VS (in \%) was calculated using the equation described by AMPTS II [30]. Total alkalinity and partial alkalinity were performed following the method described in the Standard Method procedure 2320B [37]. Triplicate samples were used for each measurement.

\section{B. Substrate}

The substrate used in this study originated from the inlet of a full-scale anaerobic digester treating domestic mixed sewage sludge (DMSS), DMSS was collected twice, about $10 \mathrm{~L}$ at each sampling. DMSS was stored at $4^{\circ} \mathrm{C}$ before use as described by Bougrier, [38].

\section{Inoculum}

An active anaerobic biomass or anaerobically digested sewage sludge (ANDS) from aforementioned anaerobic digester was used as inoculum. Two samples were collected; about $10 \mathrm{~L}$ at each sampling. ANDS was stored at $4^{\circ} \mathrm{C}$ before use as described by Nges, [39]. 
The full-scale anaerobic digester is working at the ambient mesophilic range. The $\mathrm{pH}$ of the inoculum varied from 7.2 to 7.8. The specific acetoclastic methanogenic activity (SAMA) of the inoculum for each sample was less than $0.05 \mathrm{gCH}_{4}-\mathrm{COD} / \mathrm{gVSd}$. The SAMA value from this study is lower than the value observed from digester sludge taken from a full-scale mesophilic anaerobic digester in wastewater treatment plant [40].

The intermediate alkalinity to partial alkalinity (IA/PA) ratio is showing the anaerobic process status. During the sampling day, the full-scale anaerobic digester was in stable condition, indicated by the IA/PA ratio of less than 0.3 . On the other hand, IA/PA ratio greater than 0.3 indicated the instability of the anaerobic process [41].

\section{Anaerobic Digestibility Assays}

The methane recovery from the anaerobic digestion of DMSS (as substrate) was determined using biochemical methane potential (BMP) test, conducted using AMPTS II (Fig. 1). Duran bottle of $500 \mathrm{ml}$ is a reactor where the mixture of substrate and inoculum was placed. Then the reactor was placed into the water bath (Unit A of AMPTS II); working at $37 \pm 1^{\circ} \mathrm{C}$.

The BMP assays were carried out after the sample (DMSS and ANDS) stored for 3 days. This is because the measurement of volatile solid (VS) took two days to complete. Inoculum to substrate (I/S) ratio of 2 was applied because this value was commonly applied for batch assays [40], [42].

Using I/S ratio of 2 and VS (in \%), the mass of substrate and inoculum were calculated and shown in Table 1 . The measurements were following the procedures and equations as described in the Operation and Maintenance manual of AMPTS II [30]. No additional nutrients or minerals were added to the mixture. Since the test is a batch test, no feeding or wasting was done.

Triplicate sample reactors were prepared, containing substrate and inoculum as described by others [43], [44]. In addition, duplicate blank reactors were also prepared, containing only the inoculum, at the exact mass as filled in the sample reactors [34], [45]. The substrate and inoculum, each was shaken to homogenise the solid concentration before pouring into the reactors. The reactor was prepared in sequence one after the other, to avoid the reactions of substrate and inoculum which may interfere with the results. The initial $\mathrm{pH}$ of mixture or blank was recorded before flushing with pure nitrogen gas $\left(\mathrm{N}_{2}\right)$. Then, $\mathrm{N}_{2}$ was purged into each reactor for two (2) minutes to create the anaerobic environment in the headspace. The reactor bottles were incubated at $37^{\circ} \mathrm{C} \pm 1{ }^{\circ} \mathrm{C}$ and the methane production was monitored until the production become insignificant. During the experiment, mixing was set at $160 \mathrm{rpm}$, and the $\mathrm{CH}_{4}$ content was set as $60 \%$. Luostarinen, [46] also applied the mixing of $160 \mathrm{rpm}$ for the batch reactors. The methane production varied from $60 \%$ to $69 \%$ [47]. The methane production (potential) was expressed specifically per mass volatile solid added ( $\mathrm{L} \mathrm{CH}_{4} / \mathrm{kg}$ VS added) [30], [48]. The net methane production is the difference after subtracting the methane production obtained from the samples reactors with the methane production originating from the inoculum alone (blank reactor).

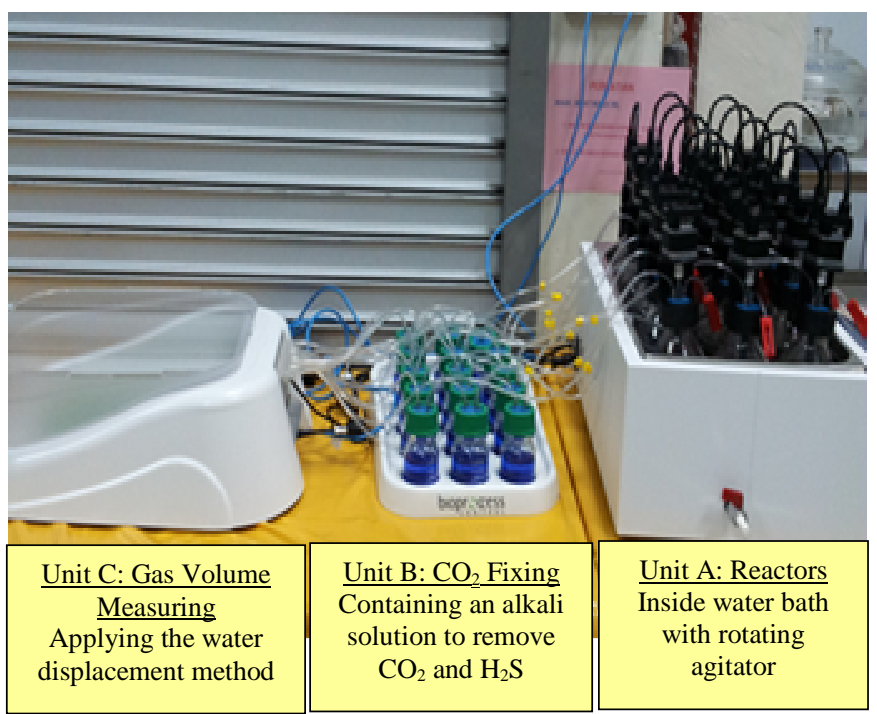

Fig. 1 AMPTS II

TABLE I

MASS OF INOCULUM (ANDS) AND SUBSTRATE (DMSS) USED FOR BMP TESTS

\begin{tabular}{|l|c|c|}
\hline Sampling date & $\mathbf{2 7 / 7 / 2 0 1 5}$ & $\mathbf{1 4 / 9 / 2 0 1 5}$ \\
\hline Total mass (g) of the mixture & 400.00 & 400.00 \\
\hline Inoculum (ANDS) mass (g) & 297.14 & 269.77 \\
\hline Substrate (DMSS) mass (g) & 102.86 & 130.23 \\
\hline
\end{tabular}

For the labelling purpose, BMP MSNT is the sample reactor containing the mixture of substrate and inoculum, while the reactor containing the only inoculum is labelled as B BMP MSNT. Each of BMP MSNT and B BMP MSNT showed the initial $\mathrm{pH}$ ranged from 6.8 to 8.0. According to Angelidaki [48], the anaerobic digestion process takes place at the $\mathrm{pH}$ ranged from 6.0 to 8.3 . Therefore, no $\mathrm{pH}$ adjustment was made.

\section{RESULTS AND DISCUSSION}

\section{A. Substrate and Inoculum Characteristics}

Generally, the substrate (DMSS) and inoculum (ANDS) characteristic vary between the two samples due to different water consumption and difficulties to control the anaerobic digestion performance [34], [37]. The organic content in DMSS from two samples fluctuated as indicated by the ratio of VS/TS. VS/TS ratios for DMSS taken on 27/7/2015 and $14 / 9 / 2015$ were 0.52 and 0.68 respectively. However, the VS/TS ratio value still bigger than 0.50 , showing that the organic content of DMSS was high. Zhang [50] also observed organic content at a range of 0.50 to 0.70 from sludge originated from wastewater treatment plant.

The organic content in ANDS was almost similar, varied from 0.63 to 0.65 . Raposo, [51] reported that digested sludge from a full-scale municipal wastewater treatment plant was having VS/TS of 0.63. Biomass in ANDS was measured in VS [10] in the form of VS (in \%). However, the significant difference was observed between two samples. VS (\%) of ANDS taken on 14/9/2015 was about three times higher than what was observed from ANDS taken on 27/7/2015. This is true due to the fact that the substrate, operating condition, and anaerobic digester microorganisms were interrelated among them [49]. 


\section{B. Methane Production}

At the last day of BMP assays, $\mathrm{pH}$ of each BMP MSNT and $\mathrm{B}$ BMP MSNT remained in the range suitable for the anaerobic process (7.1 to 8.1). Each BMP MSNT and B BMP MSNT did not show any instability of the anaerobic process, indicated by IA/PA value less than 0.3 .

Fig. 2 and Fig. 3 showed the methane accumulation during the BMP assays for samples taken on 27/7/2015 (VS/TS $=0.52)$ and 14/9/2015 (VS/TS $=0.68)$ which ends after 19 days and 21 days respectively. The inconsistent distribution of anaerobic biomass in the sample and blank reactors, indicated by the high coefficient of variation, $\mathrm{CV}$ (\%) (Table 2) resulted in the graphs as shown in Fig. 2. This is possible especially when the VS (\%) of ANDS taken on $27 / 7 / 2015$ were about $0.1 \%$.

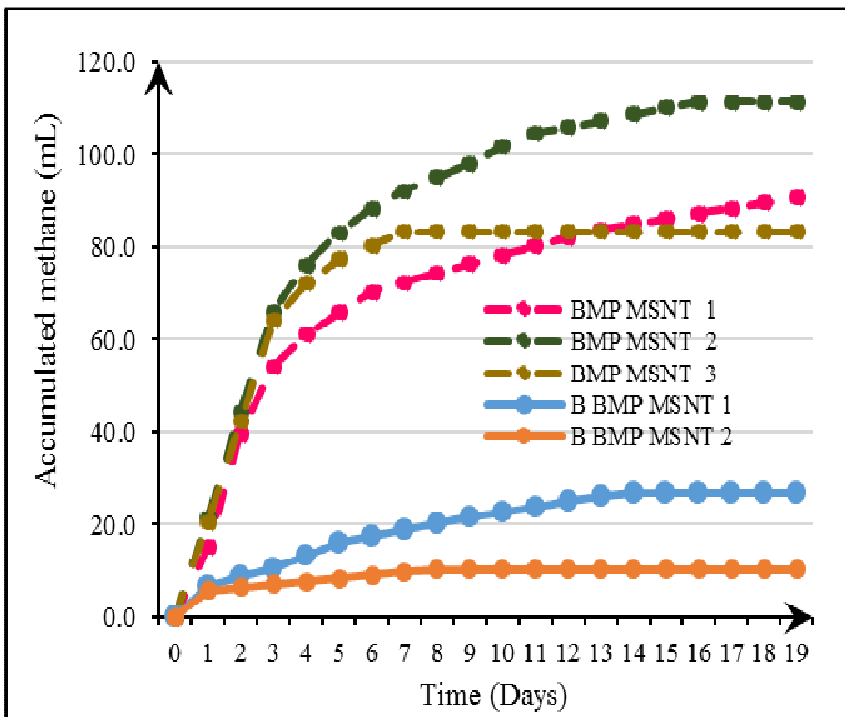

Fig. 2 Cumulative methane production from digesting DMSS; organic content of 0.52

The methane accumulation graphs for the sample taken on 14/9/2015 showed each graph plotted almost similar values for the first 10 days and gradually fluctuated towards the end. However, this was not observed from the blank reactor. The plateau condition was achievable from day seventh (7) onwards, observed from samples reactor. Other researchers using sewage sludge for BMP tests had observed the plateau condition after 15 to 20 days ([10], [12]).

The net accumulated methane for BMP assays for 19 days (sampling date: 27/7/2015) and 21 days (sampling date: 14/9/2015) was tabulated in Table 2. As expected, the higher net accumulated methane was observed from the digestion of DMSS taken on 14/9/2015. This is true because the organic content of DMSS taken on 14/9/2015 is greater $30 \%$ than the organic content of DMSS taken on 27/7/2015. Furthermore, the anaerobic biomass taken on 14/9/2015 was slightly better in producing methane (data not presented).

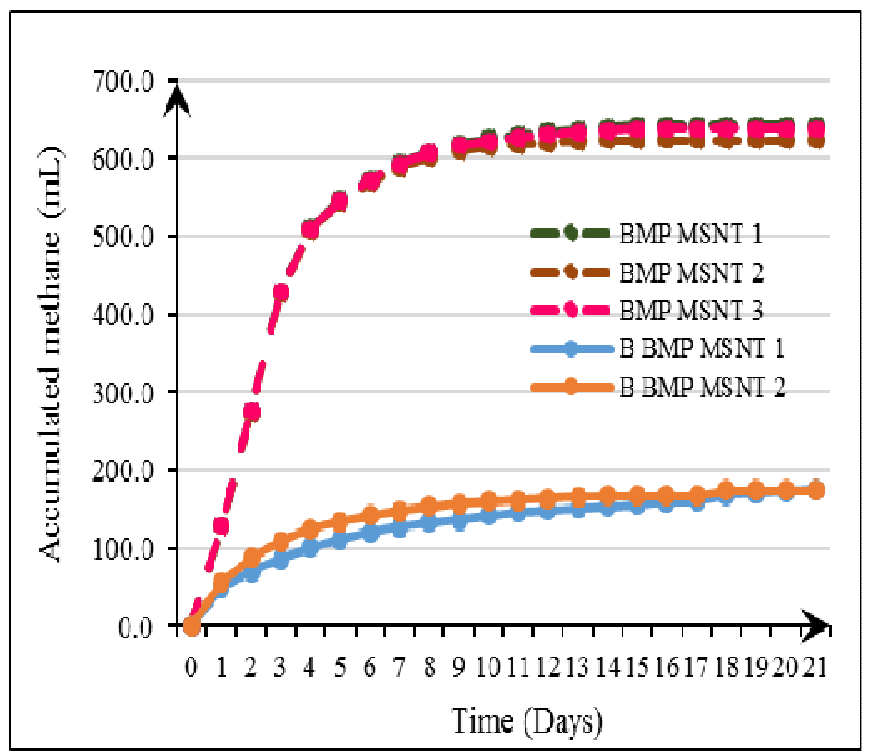

Fig. 3 Cumulative methane production from digesting DMSS; organic content of 0.68

TABLE II

NET CUMULATIVE METHANE PRODUCTION

\begin{tabular}{|c|c|c|c|}
\hline \multicolumn{2}{|c|}{ Sampling date: $27 / 7 / 2015$} & \multicolumn{2}{|c|}{ Sampling date: $14 / 9 / 2015$} \\
\hline $\begin{array}{l}\text { Sample } \\
\text { ID }\end{array}$ & $\begin{array}{l}\text { Methane } \\
\text { (mL) }\end{array}$ & $\begin{array}{l}\text { Sample } \\
\text { ID }\end{array}$ & $\begin{array}{l}\text { Methane } \\
(\mathrm{mL})\end{array}$ \\
\hline $\begin{array}{l}\text { B BMP } \\
\text { MSNT } 1\end{array}$ & 27.00 & $\begin{array}{l}\text { B BMP } \\
\text { MSNT } 1\end{array}$ & 175.00 \\
\hline $\begin{array}{l}\text { B BMP } \\
\text { MSNT }\end{array}$ & 10.30 & $\begin{array}{c}\text { B BMP } \\
\text { MSNT } 2\end{array}$ & 174.60 \\
\hline Average & 18.70 & Average & 174.80 \\
\hline Std-dev & 11.80 & Std-dev & 0.28 \\
\hline $\mathrm{CV}(\%)$ & 63.10 & $\mathrm{CV}(\%)$ & 0.16 \\
\hline $\begin{array}{c}\text { BMP } \\
\text { MSNT } 1\end{array}$ & 90.70 & $\begin{array}{c}\text { BMP } \\
\text { MSNT } 1\end{array}$ & 642.20 \\
\hline $\begin{array}{c}\text { BMP } \\
\text { MSNT } 2 \\
\end{array}$ & 111.30 & $\begin{array}{c}\text { BMP } \\
\text { MSNT } 2 \\
\end{array}$ & 623.70 \\
\hline $\begin{array}{c}\text { BMP } \\
\text { MSNT } 3\end{array}$ & 83.40 & $\begin{array}{c}\text { BMP } \\
\text { MSNT } 3\end{array}$ & 638.10 \\
\hline Average & 95.20 & Average & 634.70 \\
\hline Std-dev & 14.48 & Std-dev & 9.72 \\
\hline $\mathrm{CV}(\%)$ & 15.21 & $\mathrm{CV}(\%)$ & 1.53 \\
\hline \multicolumn{2}{|c|}{ Net Methane $(\mathrm{mL})=76.50$} & \multicolumn{2}{|c|}{ Net Methane $(\mathrm{mL})=459.90$} \\
\hline
\end{tabular}

\section{Ultimate Methane Yield}

By considering the average accumulated methane and volatile solid, VS (in g) (data not presented), the methane potential in $\mathrm{mL} \mathrm{CH}_{4} / \mathrm{g}$ VS was determined as illustrated in Fig. 4 and 5. The ultimate methane yield $\left(\mathrm{M}_{\mathrm{o}}\right)$ from digesting DMSS taken on 27/7/2016 (VS/TS $=0.52$ ) was $588.3 \mathrm{~mL}$ $\mathrm{CH}_{4} / \mathrm{g}$ VS $\left(0.59 \mathrm{~m}^{3} \mathrm{CH}_{4} / \mathrm{kg}\right.$ VS $)$ and recorded on the last day of the assay. On the contrary, the highest net ultimate methane potential of digesting DMSS taken on 14/9/2015 $(\mathrm{VS} / \mathrm{TS}=0.68)$ was $1244.5 \mathrm{~mL} \mathrm{CH}_{4} / \mathrm{g}$ VS $\left(1.24 \mathrm{~m}^{3} \mathrm{CH}_{4} / \mathrm{kg}\right.$ VS), was observed on day 15 of the assay. The net methane potential started to decrease from day 16 onwards. However, the value remained within $97.24 \%$ to $99.71 \%$ of its highest value. This showing that prolongs digestion time was not appropriate to obtain greater ultimate methane yield. 


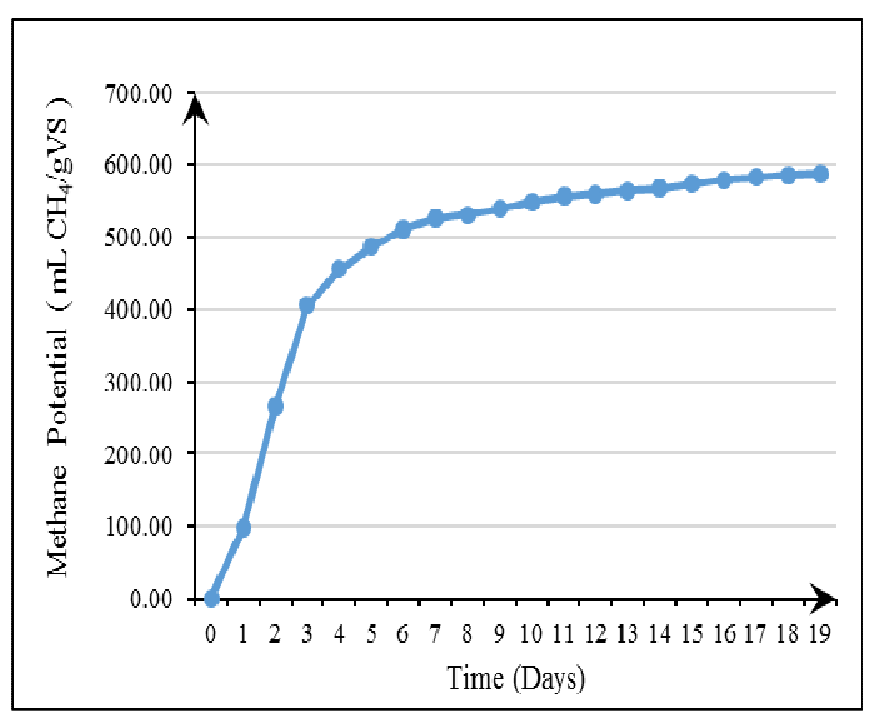

Fig. 4 Methane potential curve from BMP assay (organic content $=0.52$ )

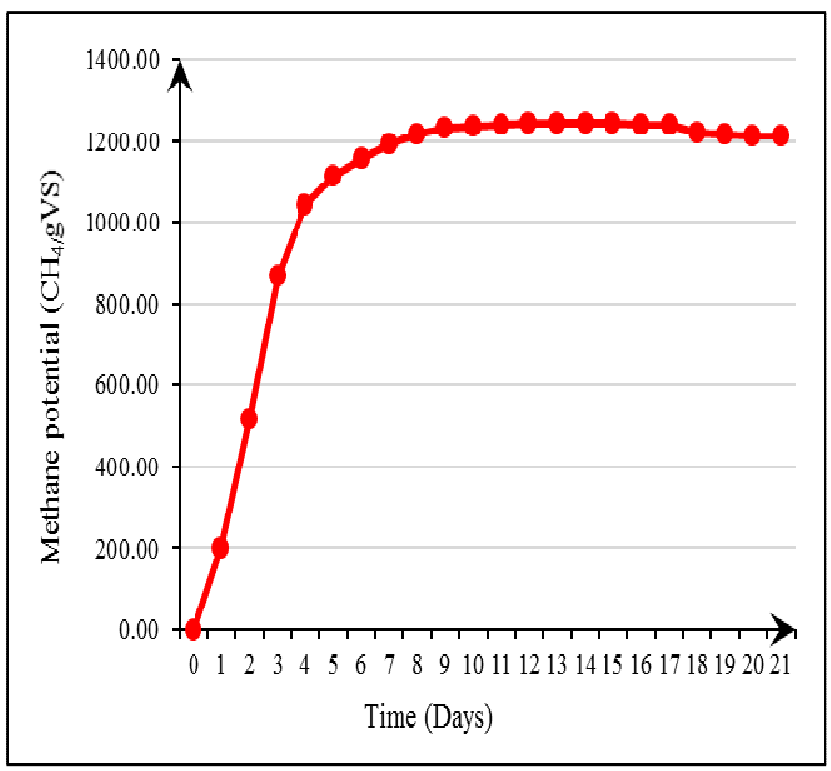

Fig. 5 Methane potential curve from BMP assay (organic content $=0.68$ )

The results indicated that the anaerobic digestion of domestic mixed sewage sludge resulted in the ultimate methane yield which is bigger that $500 \mathrm{~mL} \mathrm{CH} / \mathrm{g} \mathrm{VS}$ $\left(0.5 \mathrm{~m}^{3} \mathrm{CH}_{4} / \mathrm{kg} \mathrm{VS}\right)$. However, domestic mixed sewage sludge having higher VS/TS ratio resulted in twofold ultimate methane yield. Generally, the biogas production from a mixture of primary and secondary (biological) sludge roughly amounts to $1 \mathrm{~m}^{3}$ of biogas $/ \mathrm{kg}$ of organic solids biodegraded [1]. This study suggested the lower detention time ( $\leq 15$ days) could be adapted in designing the anaerobic tank especially for digesting the domestic mixed sewage sludge having VS/TS ratio of 0.68 .

According to reference [25], the absence of the lag phase in the methane yield curve was showing the good anaerobic biodegradability of the organic waste (targeted substrate). In addition, the BMP test in batch mode ( $/ / \mathrm{S}=2)$ of municipal sewage sludge inoculated by inoculum originated from the sewage sludge anaerobic digester the methane yield curve without lag phase observed. The origin of the inoculum positively affected the lag phase of the methane potential curve. Reference [42] used inoculum originated from two type of reactors (lab-scale and fullscale) in assessing the methane potential from municipal solid waste; the longer lag phase was observed when the municipal solid waste was inoculated with biomass from the full-scale anaerobic digester. This study observed the similar observation; lag phase was less than one (1) day for each BMP assay. This is possible due to the use of anaerobic biomass taken from the full-scale anaerobic digester as inoculum. However, the domestic mixed sewage sludge still showing a good biodegradability.

\section{Methane Production Rate}

Considering the steepest slope of each methane potential curve (Fig. 4 and 5), the methane production rate $\left(R_{m}\right)$ was calculated. The maximum methane production rates for digestion of DMSS taken on 27/7/2015 and 14/9/2015 were $6.41 \mathrm{~mL} \quad \mathrm{CH}_{4} / \mathrm{g} \quad \mathrm{VS} / \mathrm{hr}$ and $13.97 \quad \mathrm{~mL} \quad \mathrm{CH}_{4} / \mathrm{g} \quad \mathrm{VS} / \mathrm{hr}$ respectively. This lower value is expected from digestion of DMSS having lower organic content $(\mathrm{VS} / \mathrm{TS}=0.52$ ).

\section{CONCLUSIONS}

The characteristics of DMSS and ANDS vary between the two sets of samples taken on 27/7/2015 and 14/9/2015. The organic content of DMSS differed significantly from two samplings. However, the organic content of DMSS was considered high, as indicated by VS/TS ratios bigger than 0.50 (VS/TS $\geq 0.50$ ). The organic content of ANDS ranged from 0.63 to 0.65 . However, the biomass concentration as indicates by VS (in \%) differed significantly from two samplings. In practice, it is difficult to control and maintained the full-scale digester.

The methane yields from the digestion of DMSS having varies organic content (VS/TS of 0.52 and 0.68) were observed in this study. The ultimate methane yield (almost double) was observed from the anaerobic digestion of DMSS containing higher organic content (VS/TS $=0.68)$ even though the inoculum with the lower capability of producing methane was used at it was observed at day 15 . This is unexpected because the digestion of DMSS with VS/TS ratio of 0.68 was inoculated with the anaerobic biomass (ANDS) with slightly better in producing methane, indicated by slightly higher SAMA value.

The combination of DMSS with the organic content (VS/TS) less than 0.55 (VS/TS < 0.55) with the ANDS having lower SAMA value is not possible to achieve greater ultimate methane yield even after 19 days. This was shown from the digestion of samples taken on 27/7/2015.

This study was suggesting the proper selection of inoculums prior to the digestion of domestic mixed sewage sludge. The inoculum with higher SAMA value is highly recommended for obtaining the higher ultimate methane yield from the digestion of domestic mixed sewage sludge. By using this inoculum, the ultimate methane yield could be observed early. 


\section{NOMENCLATURE}

$\mathrm{M}_{\mathrm{o}} \quad$ ultimate methane yield

$\mathrm{R}_{\mathrm{m}} \quad$ methane production rate

$\mathrm{mL} \mathrm{CH}_{4} / \mathrm{g} \mathrm{VS}$

$\mathrm{mL} \mathrm{CH}_{4} / \mathrm{g} \mathrm{VS} / \mathrm{hr}$

\section{ACKNOWLEDGMENT}

The authors wished to thank Micropollutant Research Centre, Universiti Tun Hussein Onn Malaysia (UTHM) for the funding of this research. We also wish to thank R\&D and Innovation Unit, Indah Water Consortium and Office for Research, Innovation, Commercialization, and Consultancy Management (ORICC), Universiti Tun Hussein Onn Malaysia for their cooperation.

\section{REFERENCES}

[1] W. Rulkens, "Sewage Sludge as a Biomass Resource for the Production of Energy: Overview and Assessment of the Various Options ," Energy and Fuels, no. 22, pp. 9-15, 2008.

[2] L. Appels, J. Lauwers, J. Degrève, L. Helsen, B. Lievens, K. Willems, J. Van Impe, and R. Dewil, "Anaerobic digestion in global bioenergy production: Potential and research challenges," Renew. Sustain. Energy Rev., vol. 15, no. 9, pp. 4295-4301, Dec. 2011.

[3] F. Morgan-Sagastume, S. Pratt, a Karlsson, D. Cirne, P. Lant, and a Werker, "Production of volatile fatty acids by fermentation of waste activated sludge pre-treated in full-scale thermal hydrolysis plants.," Bioresour. Technol., vol. 102, no. 3, pp. 3089-97, Mar. 2011.

[4] T. Forster-Carneiro, V. Riau, and M. Pérez, "Mesophilic anaerobic digestion of sewage sludge to obtain class B biosolids: Microbiological methods development," Biomass and Bioenergy, vol. 34, no. 12, pp. 1805-1812, Dec. 2010.

[5] J. E. Burgess and B. I. Pletschke, "Hydrolytic enzymes in sewage sludge treatment : A mini-review," Water SA, vol. 34, no. 3, pp. 343350, 2008.

[6] A. A. Abd. Latiff, A. T. Abdul Karim, M. B. Ridzuan, D. E. Chuan Yeoh, and Y.-T. Hung, "Heavy Metals Removal by Crops from Land Application of Sludge," in Handbook of Environmental Engineering. Environmental Bioengineering, 11th ed., L. K. Wang, J.-H. Tay, S. T.-L. Tay, and Y.-T. Hung, Eds. London: Humana Press, 2010, pp. 211-231.

[7] L. Appels, J. Baeyens, J. Degrève, and R. Dewil, "Principles and Potential of The Anaerobic Digestion of Waste-Activated Sludge," Prog. Energy Combust. Sci., vol. 34, no. 6, pp. 755-781, Dec. 2008.

[8] C. Bougrier, J.-P. Delgenès, and H. Carrère, "Combination of Thermal Treatments and Anaerobic Digestion to Reduce Sewage Sludge Quantity and Improve Biogas Yield," Process Saf. Environ. Prot., vol. 84, no. 4, pp. 280-284, Jul. 2006.

[9] H. Yi, Y. Han, and Y. Zhuo, "Effect of Combined Pretreatment of Waste Activated Sludge for Anaerobic Digestion Process," Procedia Environ. Sci., vol. 18, pp. 716-721, Jan. 2013.

[10] C. Arnaiz, J. C. Gutierrez, and J. Lebrato, "Biomass stabilization in the anaerobic digestion of wastewater sludges," Bioresour. Technol., vol. 97, no. 10, pp. 1179-1184, 2006.

[11] M. Kuglarz, D. Karakashev, and I. Angelidaki, "Microwave and thermal pretreatment as methods for increasing the biogas potential of secondary sludge from municipal wastewater treatment plants.," Bioresour. Technol., vol. 134, pp. 290-7, Apr. 2013.

[12] J. A. C. Rivero, N. Madhavan, M. T. Suidan, P. Ginestet, and J. Audic, "Enhancement of Anaerobic Digestion of Excess Municipal Sludge with Thermal and / or Oxidative Treatment," J. Environ. Eng., no. 132 , pp. $638-644,2006$.

[13] C. A. Wilson and J. T. Novak, "Hydrolysis of Macromolecular Components of Primary and Secondary Wastewater Sludge by Thermal Hydrolytic Pretreatment.," Water Res., vol. 43, no. 18, pp. 4489-98, Oct. 2009.

[14] K. Wang, "Review On Increasing Efficiency of Biogas Production From Sewage Sludge," Royal Institute of Technology (KTH), 2012.

[15] A. Mottet, E. François, E. Latrille, J. P. Steyer, S. Déléris, F. Vedrenne, and H. Carrère, "Estimating anaerobic biodegradability indicators for waste activated sludge," Chem. Eng. J., vol. 160, no. 2, pp. 488-496, Jun. 2010.

[16] R. Jones, W. Parker, Z. Khan, S. Murthy, and M. Rupke,
"Characterization of sludges for predicting anaerobic digester performance.," Wat. Sci.Tech, vol. 57, no. 5, pp. 721-726, Jan. 2008.

[17] D. Bolzonella, C. Cavinato, F. Fatone, P. Pavan, and F. Cecchi, "High rate Mesophilic, Thermophilic, and Temperature-Phased Anaerobic Digestion of Waste Activated Sludge: A Pilot Scale Study.,"Waste Manag., vol. 32, no. 6, pp. 1196-201, Jun. 2012.

[18] S. E. Hosseini and M. A. Wahid, "Feasibility study of biogas production and utilization as a source of renewable energy in Malaysia," Renew. Sustain. Energy Rev., vol. 19, pp. 454-462, 2013.

[19] R. Morris, A. Schauer-Gimenez, U. Bhattad, C. Kearney, C. a Struble, D. Zitomer, and J. S. Maki, "Methyl-coenzyme M reductase (mcrA) gene abundance correlates with activity measurements of methanogenic $\mathrm{H}_{2} / \mathrm{CO}_{2}$-enriched anaerobic biomass.," Microb. Biotechnol., vol. 7, no. 1, pp. 77-84, Jan. 2014.

[20] S. M. Cowgill, "Optimised Biogas Production At Malabar Sewage Treatment Plant," Murdoch University, 2011.

[21] S. J. Lim and P. Fox, "Biochemical methane potential (BMP) test for thickened sludge using anaerobic granular sludge at different inoculum/substrate ratios," Biotechnol. Bioprocess Eng., vol. 18, no. 2, pp. 306-312, May 2013.

[22] L. Feng, Y. Li, C. Chen, X. Liu, X. Xiao, R. Zhang, Y. He, and G. Liu, "Biochemical Methane Potential (BMP) of Vinegar Residue and the Influence of Feed to Inoculum Ratios on Biogas Production," BioResources, vol. 8, no. 2, pp. 2487-2498, 2013.

[23] J.-C. Frigon, P. Mehta, and S. R. Guiot, "Impact of mechanical, chemical and enzymatic pre-treatments on the methane yield from the anaerobic digestion of switchgrass," Biomass and Bioenergy, vol. 36, pp. 1-11, Jan. 2012.

[24] J. Lin, Y. Ma, A. C. Chao, and C. Huang, "BMP test on Chemically Pretreated Sludge,” Bioresour. Technol., vol. 68, pp. 187-192, 1999.

[25] A. J. Cavaleiro, T. Ferreira, F. Pereira, G. Tommaso, and M. M. Alves, "Biochemical methane potential of raw and pre-treated meatprocessing wastes.," Bioresour. Technol., vol. 129, pp. 519-525, Feb. 2013.

[26] J. Li, S. M. Zicari, Z. Cui, and R. Zhang, "Processing anaerobic sludge for extended storage as anaerobic digester inoculum.," Bioresour. Technol., vol. 166, pp. 201-10, Aug. 2014.

[27] G. Zhen, X. Lu, T. Kobayashi, Y. Li, K. Xu, and Y. Zhao, "Mesophilic anaerobic co-digestion of waste activated sludge and Egeria densa : Performance assessment and kinetic analysis," Appl. Energy, vol. 148, pp. 78-86, 2015.

[28] S. Kolbl, A. Paloczi, J. Panjan, and B. Stres, "Addressing case specific biogas plant tasks: Industry oriented methane yields derived from 5L Automatic Methane Potential Test Systems in batch or semicontinuous tests using realistic inocula, substrate particle sizes and organic loading," Bioresour. Technol., vol. 153, pp. 180-188, 2014.

[29] S. Strömberg, M. Nistor, and J. Liu, "Towards eliminating systematic errors caused by the experimental conditions in Biochemical Methane Potential (BMP) tests.," Waste Manag., vol. 34, no. 11, pp. 1939-48, Nov. 2014.

[30] Bioprocess Control, AMPTS II Operation and Maintenance Manual. Sweden, 2014.

[31] S. Astals, M. Esteban-Gutiérrez, T. Fernández-Arévalo, E. Aymerich, J. L. García-Heras, and J. Mata-Alvarez, "Anaerobic digestion of seven different sewage sludges: A biodegradability and modelling study.,"Water Res., pp. 1-11, Jul. 2013.

[32] T. Mao, S. Y. Hong, K. Y. Show, J. H. Tay, and D. J. Lee, "A comparison of ultrasound treatment on primary and secondary sludges.," Water Sci. Technol., vol. 50, no. 9, pp. 91-7, Jan. 2004.

[33] L. Y. Feng, L. Q. Yang, L. X. Zhang, H. L. Chen, and J. Chen, "Improved methane production from waste activated sludge with low organic content by alkaline pretreatment at $\mathrm{pH} 10 ., "$ Water Sci. Technol., vol. 68, no. 7, pp. 1591-8, Jan. 2013.

[34] Y. Yan, H. Chen, W. Xu, Q. He, and Q. Zhou, "Enhancement of Biochemical Methane Potential from Excess Sludge with Low Organic Content by Mild Thermal Pretreatment," Biochem. Eng. J., vol. 70, pp. 127-134, Jan. 2013.

[35] L. Regueiro, P. Veiga, M. Figueroa, J. Alonso-Gutierrez, A. J. M Stams, J. M. Lema, and M. Carballa, "Relationship between microbial activity and microbial community structure in six full-scale anaerobic digesters.," Microbiol. Res., vol. 167, no. 10, pp. 581-9, Dec. 2012.

[36] C. D. Muller and J. T. Novak, "The Impact of Floc Metals on Conventional and Enhanced Mesophilic Anaerobic Digestion Technologies," in WEFTEC 2007, 2007.

[37] American Public Health Association, Standard Methods forThe Examination of Water and Wastewater., 20 th., vol. 4, no. 3. 
American Public Health Association, American Water Works Association, Water Environment Federation, 1999.

[38] C. Bougrier, J. P. Delgen, and H. Carr' ere *, "Impacts of thermal pre-treatments on the semi-continuous anaerobic digestion of waste activated sludge," Biochem. Eng. J., vol. 34, pp. 20-27, 2007.

[39] I. A. Nges and J. Liu, "Effects of anaerobic pre-treatment on the degradation of dewatered-sewage sludge," Renew. Energy, vol. 34, no. 7, pp. 1795-1800, Jul. 2009

[40] D. P. Ho, P. D. Jensen, and D. J. Batstone, "Methanosarcinaceae and acetate-oxidizing pathways dominate in high-rate thermophilic anaerobic digestion of waste-activated sludge," Appl. Environ. Microbiol., vol. 79, no. 20, pp. 6491-6500, 2013.

[41] J. C. Ripley, L.E. Boyle, W.C., Converse, "Improved alkalimetric monitoring for anaerobic digestion of high-strength wastes.," J.WPCF, vol. 58, no. 5, pp. 406-411, 1983.

[42] A. P. Trzcinski and D. C. Stuckey, "Determination of the Hydrolysis Constant in the Biochemical Methane Potential Test of Municipal Solid Waste," Environ. Eng. Sci., vol. 29, no. 9, pp. 848-854, Sep. 2012.

[43] S. Şahinkaya and M. F. Sevimli, "Sono-thermal pre-treatment of Waste Activated Sludge Before Anaerobic Digestion.," Ultrason. Sonochem., vol. 20, no. 1, pp. 587-94, Jan. 2013.

[44] T. S. O. Souza, L. C. Ferreira, I. Sapkaite, S. I. Pérez-Elvira, and F. Fdz-Polanco, "Thermal pretreatment and hydraulic retention time in continuous digesters fed with sewage sludge: assessment using the ADM1.," Bioresour. Technol., vol. 148, pp. 317-24, Nov. 2013.
[45] G. Zhen, X. Lu, Y.-Y. Li, and Y. Zhao, "Combined electrical-alkali pretreatment to increase the anaerobic hydrolysis rate of waste activated sludge during anaerobic digestion," Appl. Energy, vol. 128, pp. 93-102, Sep. 2014.

[46] S. Luostarinen, S. Luste, and M. Sillanpää, "Increased biogas production at wastewater treatment plants through co-digestion of sewage sludge with grease trap sludge from a meat processing plant.," Bioresour. Technol., vol. 100, no. 1, pp. 79-85, Jan. 2009.

[47] H. W. Zhao and T. Viraraghavan, "Analysis of the performance of an anaerobic digestion system at the Regina Wastewater Treatment Plant.," Bioresour. Technol., vol. 95, no. 3, pp. 301-7, Dec. 2004.

[48] I. Angelidaki and W. Sanders, "Assessment of the anaerobic biodegradability of macropollutants," Rev. Environ. Sci. Bio/Technology, vol. 3, no. 2, pp. 117-129, 2004.

[49] J. Williams, H. Williams, R. Dinsdale, A. Guwy, and S. Esteves, "Monitoring methanogenic population dynamics in a full-scale anaerobic digester to facilitate operational management.," Bioresour. Technol., vol. 140, pp. 234-42, Jul. 2013.

[50] L. Zhang, J. Yin, L. Liu, and L. Zang, "Mesophilic Two-Phase Anaerobic Digestion of Waste Activated Sludge with Different VS Contents," in 3rd International Conference on Bioinformatics and Biomedical Engineering, 2009, pp. 1-4.

[51] F. Raposo, C. J. Banks, I. Siegert, S. Heaven, and R. Borja, "Influence of inoculum to substrate ratio on the biochemical methane potential of maize in batch tests," Process Biochem., vol. 41, no. 6 , pp. 1444-1450, Jun. 2006. 